\title{
11. PITHONELLOID CALCAREOUS DINOFLAGELLATES FROM THE UPPER CRETACEOUS AND CENOZOIC OF THE SOUTHEASTERN ATLANTIC OCEAN, DEEP SEA DRILLING PROJECT LEG 741
}

\author{
Dieter K. Fütterer, Geologisch-Paläontologisches Institut, Universität Kiel, \\ D-2300 Kiel, Federal Republic of Germany
}

\begin{abstract}
Two new species, three new forms in open nomenclature and two previously known species of the genus Pithonella (sensu Bolli, 1974), attributed to the dinoflagellate family Peridiniaceae are described from Upper Cretaceous to lower Pleistocene sediments of the Walvis Ridge, southeastern Atlantic Ocean. It is the first time that pithonelloid calcareous dinoflagellates are described from sediment younger than early Paleocene.
\end{abstract}

\section{INTRODUCTION}

Many species of the incertae sedis family Calcisphaerulidae have been reported previously from various DSDP core sections (Bolli, 1974, Leg 27; 1978a, Leg 40; 1978b, Leg 44; 1980, Leg 50; Rögl, 1976, Leg 35; Pflaumann and Krasheninnikov, 1978, Leg 41). Most of them were included in the genus Pithonella following the system discussed in detail by Bolli (1974); only a few species were included in the genus Bonetocardiella.

Classification of Pithonella has been controversial for a long time (e.g., Masters and Scott, 1978). However, the dinoflagellate nature of these forms as described by Bolli (1974) was proved by Keupp $(1979,1980$, 1981), who described a complete peridinoid cyst paratabulation on the inside wall surface of $P$. patriciagreeleyae attributing the genus Pithonella to the dinoflagellate family Peridiniaceae. But there is still some uncertainty whether Pithonella sensu Bolli (1974) strictly corresponds to Pithonella Lorenz 1902 as emended by Bignot and Lezaud (1964). Scanning electron microscope (SEM) investigations of Pithonella sensu Bignot and Lezaud by Villain (1977) exhibit ultrastructural test patterns completely different from those known from $\mathrm{Pi}$ thonella sensu Bolli.

Despite this controversy, all authors describing $\mathrm{Pi}$ thonella from DSDP core material used the system introduced by Bolli (1974). Because of this and the fact that no topotypic material has been investigated specifically for this study, the genus Pithonella is still treated in the sense of Bolli (1974) in the present chapter.

The stratigraphic distribution of Pithonella in DSDP cores shows three distinctly different groups of species: (1) Rich and diverse assemblages occur from the Upper Jurassic through the Lower Cretaceous. (2) Rich but less diverse assemblages are present in the Upper Cretaceous from the Coniacian to the Maestrichtian (Bolli, 1974, 1978a, Pflaumann and Krasheninnikov, 1978). (3) Very

\footnotetext{
${ }^{1}$ Moore, T. C., Jr., Rabinowitz, P. D., et al., Init. Repts. DSDP, 74: Washington (U.S. Govt. Printing Office).
}

poor assemblages are restricted to the early Paleocene (Rögl, 1976, Bolli, 1978a). This indicates a continuous decrease of species diversity from Early Cretaceous to early Paleocene. To date no species of Pithonella from younger Cenozoic sediments have been described.

In pelagic sediments recovered during Leg 74 (Fig. 1) from the Walvis Ridge area of the southeastern Atlantic Ocean, specimens of Pithonella were found to be present in minor abundance in all core sections from the Upper Cretaceous to Recent. The main aim of this chapter is to show the stratigraphic range and nature of the species observed. Special emphasis is given to the species distribution around the Cretaceous/Tertiary boundary.

\section{MATERIAL AND METHODS}

The distribution of Pithonella species was investigated in samples from Holes 525A, 526, and 527. The last two holes were chosen in order to cover and compare different paleo-water-depths from shallow to deep. Holes 526 and 527 were drilled in modern water depths of 1054 and $4428 \mathrm{~m}$, respectively. Cores from Hole 525A were sampled only around the Cretaceous/Tertiary boundary for comparison with corresponding sections of Hole 527.

Lithologically all samples represent pelagic foraminifer nannofossil ooze and chalk, respectively. Preservation is quite good, although slightly increasing modifications by diagenetic crystal overgrowth are observed with increasing core depth and age.

All samples were washed through a $40-\mu \mathrm{m}$ mesh sieve. The material $<40 \mu \mathrm{m}$ was fractionated by sedimentation analyses. The $6-40 \mu \mathrm{m}$ fractions were mounted on scanning electron microscope (SEM) stubs and coated twice with carbon and gold palladium for examination.

Samples containing Pithonella species are listed on Table 1. The relative abundance of each species refers to frequencies counted directly from the SEM screen and calculated per section across the SEM stub (10 mm in diameter). It is given as follows: $F$, few (5-15 specimens); $R$, rare (1-5 specimens); $r$, very rare (less than 1 whole specimen). Stratigraphic classification of the samples is according to the Initial Core Descriptions.

\section{STRATIGRAPHIC DISTRIBUTION}

Four species, Pithonella krasheninnikovi, $P$. cylindrica, and the newly described $P$. globos $a$ and $P$. sp. 1 occur in the late Maestrichtian (Table 2). Only two, $P$. krasheninnikovi and P. globosa, pass the Cretaceous/ Tertiary boundary into the G. eugubina Zone of the early Danian, where they rapidly disappear. 


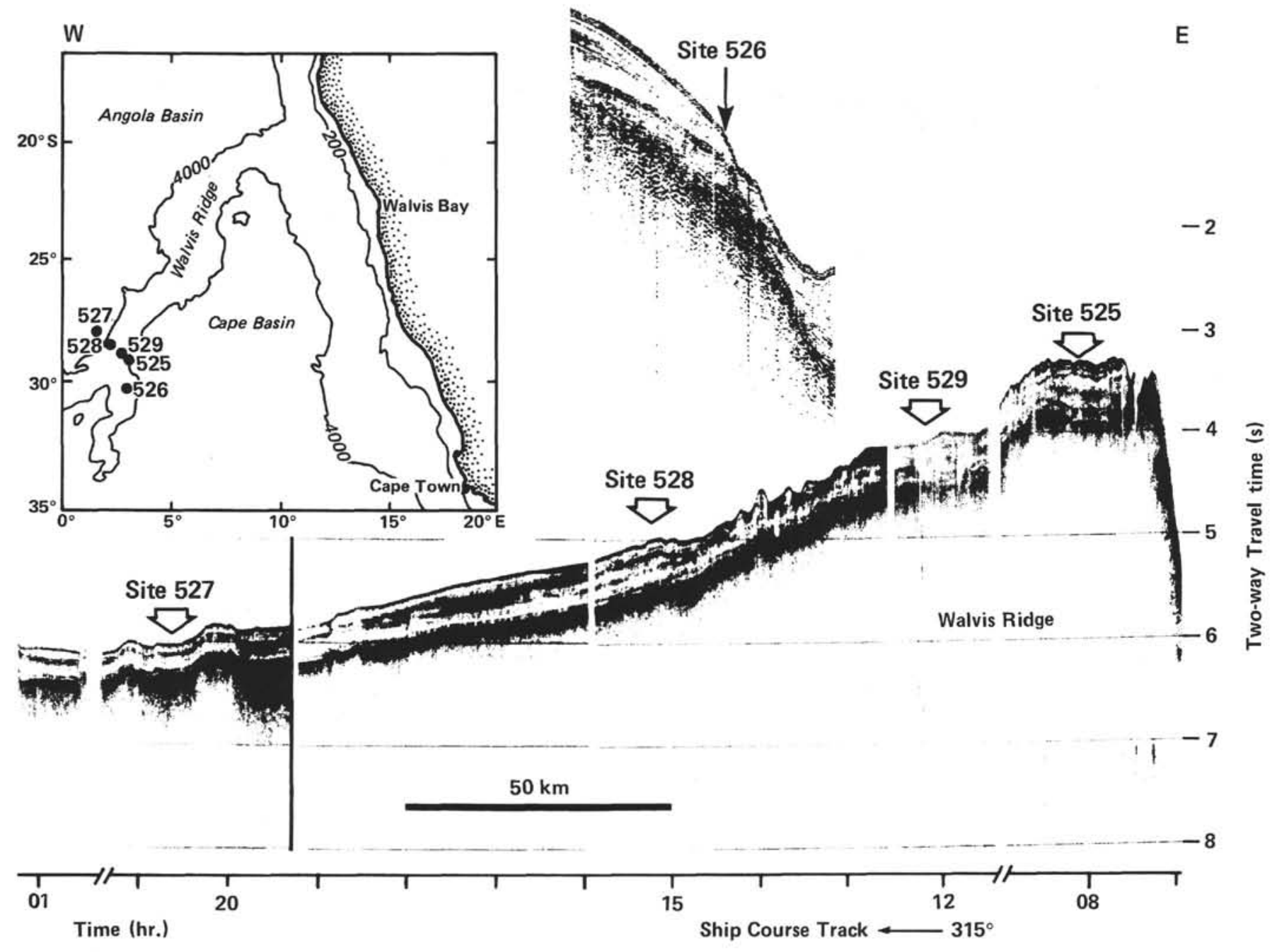

Figure 1. Index map showing geographic position and bathymetry of the Walvis Ridge and locations of Leg 74 Sites 525-529.

Three new species, $P$. parva, $P$. sp. 2, and $P$. sp. 3 , are present in the Cenozoic. $P$. parva is a long-ranging species that appears in the early Danian (P1b-c, NP1) and continues at least into the early Pleistocene (NN19/20). It seems to be more frequent in the sediments from the shallow water of Hole 526 than in those from the deeper water of Hole 527. But the differences are not so great as to cause us to conclude that at the Walvis Ridge Pithonella has a clear preference for shallow water, as reported from the Cretaceous of other regions (e.g., Bein and Reiss, 1976). $P$. sp. 2 and $P$. sp. 3 occur only in very low numbers in Oligocene to (probably) Miocene sections.

\section{MORPHOLOGICAL CRITERIA}

Various morphological criteria have been used for taxonomic classification of pithonelloid calcareous dinoflagellates. Certain disagreements as to classification derive from the different methods used, such as light microscopy and scanning electron microscopy (SEM) or thin section examination and investigation of isolated specimens, respectively. However, the main difficulties arise from significantly different points of view with re- spect to (1) primary species variability, (2) variability caused by ecological influences, and (3) secondary variability produced by diagenetic crystal overgrowth or partial dissolution.

Bolli (1974) used size and shape of the test or cyst, presence, size and shape of an aperture, number of layers forming the cyst wall, size, shape and arrangement of crystals in each layer, as well as inner and outer surface patterns as taxonomic features to describe 19 new species included in the genus Pithonella. He confined species variability within very narrow limits without discussing secondary diagenetic effects. This taxonomic system was used later in the same sense (Bolli, 1974) by Pflaumann and Krasheninnikov (1978), Rögl (1976), and Bolli (1978a, 1978b, 1980).

Masters and Scott (1978) lay particular stress on diagenetic features. They interpret the multilayered cyst walls described by Wanner (1940), Vogler (1941), Bolli (1974), and Bein and Reiss (1976) to be "diagenetic sparry calcite that encrust the test wall, which may form upon either or both the external or internal surfaces of the wall." They also declare the number of layers to be of no taxonomic value. Though morphological modifi- 
Table 1. Occurrence of Pithonella species in Leg 74 samples. For symbol explanation see text.

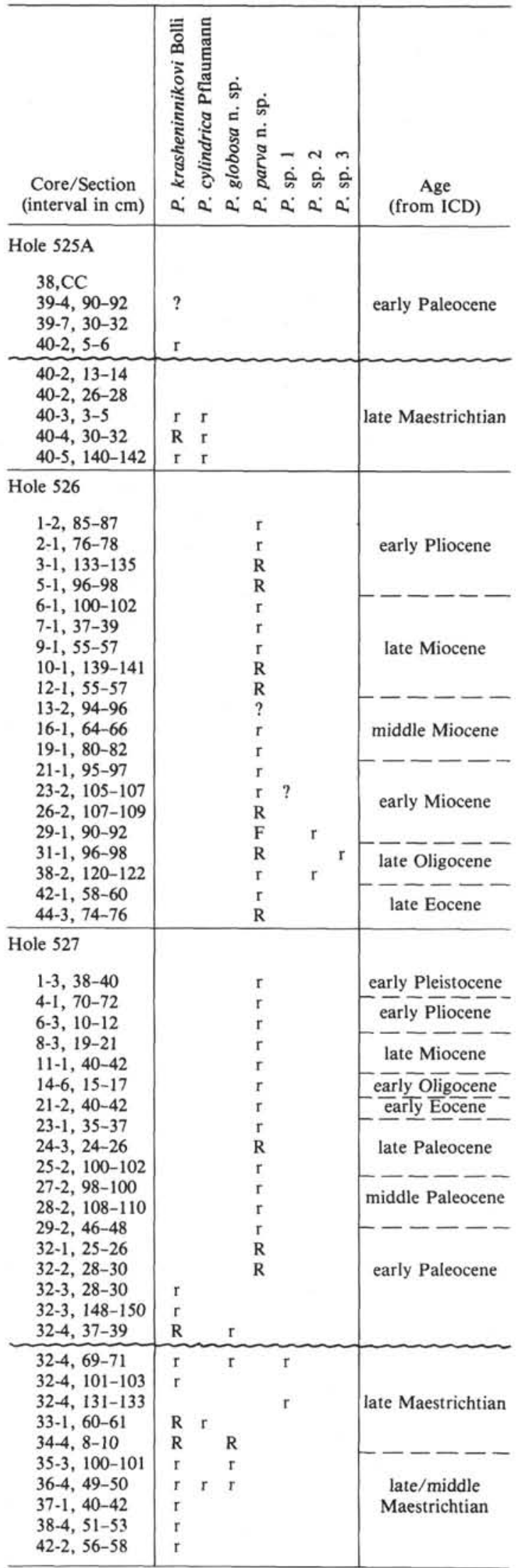

Table 2. Stratigraphic ranges of Pithonella species in Upper Cretaceous and Cenozoic sediments based on SEM investigations (according to Pflaumann and Krasheninnikov, 1978, and this chapter).

\begin{tabular}{|c|c|c|}
\hline \multirow[t]{2}{*}{ Period } & Epoch & 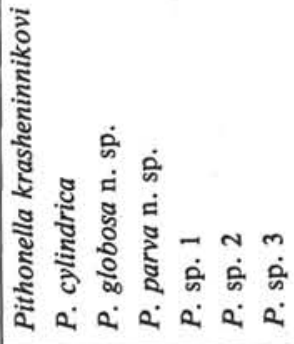 \\
\hline & Pleistocene & \\
\hline \multirow{5}{*}{ Tertiary } & Pliocene & \\
\hline & Miocene & \\
\hline & Oligocene & I. \\
\hline & Eocene & \\
\hline & Paleocene & \\
\hline \multirow{4}{*}{$\begin{array}{c}\text { Upper } \\
\text { Cretaceous }\end{array}$} & Maestrichtian & 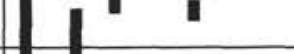 \\
\hline & Campanian & \\
\hline & Santonian & \\
\hline & Coniacian & \\
\hline
\end{tabular}

cations caused by diagenetic crystal overgrowth are well known from micro- and nannofossils, the latter conclusion seems to be too sweeping.

Keupp (1981), describing Lower Cretaceous calcareous dinoflagellates, interprets wide variability in size and shape of the cysts, size and outline of aperture, number and thickness of wall layers, as well as size and habitus of layer-forming crystals to be the result mainly of ecological changes due to changing environmental parameters. He found crystal orientation to be the only feature not so influenced and as a consequence combined several morphotypes into a few superposed units. Furthermore, Keupp (1981) denied that diagenesis had affected the material studied by him.

In general the taxonomic criteria summarized in Bolli (1974) are used in the present investigation. However, variability of distinct features-for example, size and shape of the cysts-is considered within a wider framework. Diagenetic modifications of features-above all thickness of wall layers and size and shape of crystalsare noted and interpreted if possible.

\section{TAXONOMY}

That pithonelloid calcispheres are definitely calcareous dinoflagellate cysts has been proved with certainty by Keupp (1980). Being cysts, their systematic treatment is possible only by a morphotypic parataxonomy which at a higher level can be related by reflected paratabulation to an orthotaxonomy based on the thecate phase of the dinoflagellate life cycle.

\section{Family PERIDINIACEAE Lindemann,} Genus PITHONELLA Lorenz, 1902

The genus Pithonella is used here in the sense of Bolli (1974), which differs considerably from that of Bignot and Lezaud (1964). It 
represents resting cysts of peridinoid dinoflagellates (Keupp, 1979, 1980, 1981).

Diagnosis. The single-chambered cyst ranges from an elongated cylinder or ovoid to a sphere. Cyst size varies from 40 to $140 \mu \mathrm{m}$. Wall thickness varies greatly, is single- or multilayered, and consists of calcite crystals of different size, shape, and arrangement. Crystal orientation in the distal layer is either oblique or parallel to the cyst surface. An irregularly circular apical aperture may be present.

The known stratigraphic range is from Upper Jurassic to lower Pleistocene. Highest abundance and diversity are from the Lower and Upper Cretaceous.

\section{Pithonella krasheninnikovi Bolli}

(Plate 1, Figs. 1-8)

*Pithonella krasheninnikovi $\mathrm{n}$. sp. Bolli, 1974, p. 856, pl. 7, figs. 1-5; pl. 18 , figs. $10-12$; pl. 19 , figs. $1-12$; pl. 20 , figs. 1-4; pl. 24 , figs. $1-2$.

Pithonella krasheninnikovi Bolli. Pflaumann and Krasheninnikov, 1978 , p. 822 , pl. 4 , figs. $1-6$.

Description from SEM examination. The elongated ovoidal cyst ranges from $50-135 \mu \mathrm{m}$ in length and $35-90 \mu \mathrm{m}$ in width (Plate 1, Figs. $1-3)$. The width:length ratio is between $1: 1.9$ and $1: 1.3$. A circular aperture is present slightly asymmetrically at one pole. Its size varies from $15-35 \mu \mathrm{m}$ in diameter.

The cyst wall consists of two layers. The outer layer measures $1.5-3 \mu \mathrm{m}$ in thickness. The small, prismatic, blade-like crystals, about $2-4 \mu \mathrm{m}$ in length and $0.5-1 \mu \mathrm{m}$ in diameter, are arranged oblique to the surface externally revealing a somewhat porous surface pattern. The crystal habitus of the outer layer varies widely (Plate 1, Figs. 4-6) and is probably a diagenetic effect. In many cases the outer layer is partially or completely removed.

The inner layer, about $5 \mu \mathrm{m}$ thick, consists of densely packed, heavy, rhombohedral crystals arranged with the long axis perpendicular to the surface, which gives a very characteristic surface pattern (Plate 1, Figs. 7-8). Increasing diagenesis can produce an even or smooth surface pattern.

Occurrence. Sections $525 \mathrm{~A}-40-5$ to $525 \mathrm{~A}-39-4$ and $527-42-2$ to 527-32-2.

Age. Middle-late Maestrichtian to early Danian.

Remarks. Sporadically occurring single-layer specimens show very large rhombohedral crystals (Plate 1, Fig. 9) and are interpreted as extreme types of isolated inner layers. This type is provisionally included with $P$. krasheninnikovi. Compared with the specimens described by Bolli (1974), these are less oblong than ventricose.

\section{Pithonella cylindrica Pflaumann and Krasheninnikov}

*Pithonella cylindrica $\mathrm{n}$. sp. Pflaumann and Krasheninnikov, 1978, p. 822 , pl. 5, figs. $1-4$.

Description from SEM examination. The cyst shows an elongated cylindrical outline, subspherical at each pole, where an irregular circular aperture is situated slightly asymmetrically. The cyst wall is twolayered and shows ultrastructural patterns identical to those of $P$. krasheninnikovi.

Occurrence. Sections $525 \mathrm{~A}-40-5$ to $525 \mathrm{~A}-40-3$ and $527-36-4$ to 527-33-1.

Age. Middle to late Maestrichtian.

Remarks. This species is distinguishable from $P$. krasheninnikovi by its cylindrical outline only.

\section{Pithonella globosa n. sp. (Plate 2, Figs. 1-9)}

Description from SEM examination. Cyst strictly spherical, ranging from 84-132 $\mu \mathrm{m}$ in diameter (Plate 2, Figs. 1, 4, 7). The wall is two-layered and 9-15 $\mu \mathrm{m}$ thick. The inner wall, about 6-9 $\mu \mathrm{m}$ thick, consists of heavy sparry crystals (Plate 2, Fig. 6) oriented perpendicular to the surface, where the euheudral rhombohedral crystals reveal a very characteristic surface pattern (Plate 2, Fig. 8).

The outer layer, about 3-6 $\mu \mathrm{m}$ thick, consists of smaller rhombohedral prisms or blades, $1-2 \mu \mathrm{m}$ in diameter, oriented sightly oblique to the surface (Plate 2, Figs. 5-6). Crystal arrangements on the distal surface create a porous or reticulated surface pattern.

An irregularly rimmed aperture $(25-40 \mu \mathrm{m}$ in diameter, which is about $25-35 \%$ of the cyst diameter) is present on many specimens but may be absent.
Remarks. The reticulated pattern of the distal surface of the outer layer resembles Thoracosphaera albatrosiana, but its internal ultrastructural crystal arrangement is completely different. The sparry crystal habitus of the inner layer is most probably a diagenetic effect of crystal growth, judging by the nannofossils incorporated into the growing crystals (Plate 2, Fig. 3).

Holotype. Diameter $102 \mu \mathrm{m}$, aperture $25 \mu \mathrm{m}$; inner wall thickness about $6 \mu \mathrm{m}$, outer wall thickness about $3 \mu \mathrm{m}$; Plate 2, Figs. 1-3; SEM photograph Nos. 91621-91623, film No. 2622/51-55; SEM stub No. 126/3; depository: Geol.-Paläont. Institut, University Kiel.

Type locality and stratum typicum. DSDP Leg 74, Hole 527, Sample 527-34-4, 8-10 cm, Walvis Ridge, Southeast Atlantic Ocean. Late Maestrichtian nannofossil mudstone.

Derivatio nominis. globosus $($ Latin $)=$ spherical.

Age and range of species. $P$. globosa is present rare to very rare from late-middle Maestrichtian (L. quadratus/A. mayaroensis; Sample $527-36-4,49-50 \mathrm{~cm}$ ) to early Danian (G. eugubina; Sample 527$34-4,37-39 \mathrm{~cm})$.

Pithonella parva n. sp.

(Plate 3, Figs. 1-10; Plate 4, Figs. 8-9)

Description from SEM examination. Cyst slightly ovoid to spherical, ranging from $37-67 \mu \mathrm{m}$ in length and $35-53 \mu \mathrm{m}$ in diameter (Plate 3 , Figs. 1-3). Width to length ratio in ovoid specimens is up to $1: 1.26$ (Fig. 2). The wall is two-layered and 2-6 $\mu \mathrm{m}$ thick. The inner wall seen in "young," diagenetically unaltered specimens (Plate 3, Fig. 8) is less than $1 \mu \mathrm{m}$ thick and is composed of small granular to slightly prismatic crystals oriented subparallel or oblique to the surface. With increasing age and diagenetic overgrowth the crystals thicken (Plate 3, Fig. 3 ), as does the inner layer (Plate 3, Fig. 9), which finally can exceed the outer layer in thickness (Plate 3, Fig. 10). Crystal orientation of the inner layer reveals a very characteristic distal surface pattern which is to be seen after removal of the outer layer (Plate 3, Fig. 7; Plate 4, Figs. 8-9). The outer layer is about $2-4 \mu \mathrm{m}$ thick. It is composed of plate-shaped rhombohedral crystals of approximately 1-2 $\mu \mathrm{m}$ in width, 2-4 $\mu \mathrm{m}$ in length, and $0.3-0.8 \mu \mathrm{m}$ in thickness transposed toward each other and interpenetrating (Plate 3, Figs. 5, 9). The long axis of the crystals is oriented more or less perpendicular to the surface. The ultrastructure of the outer layer crystals is composed of minute granular crystallites (Plate 3, Fig. 4) which fuse with increasing diagenesis, producing smooth crystal faces and the characteristic distal surface pat-

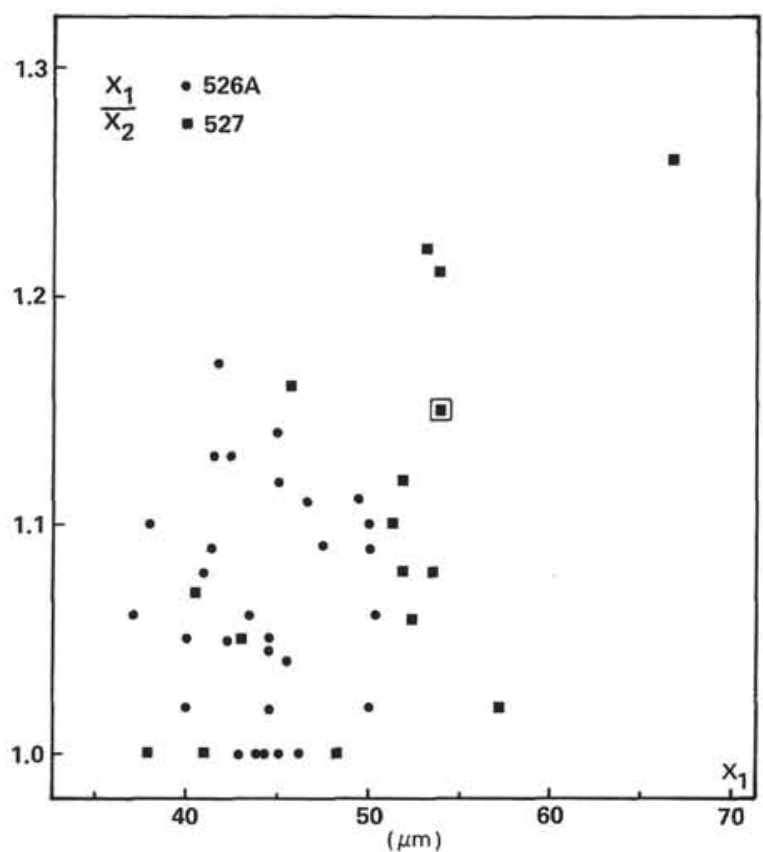

Figure 2. Variation of size and shape of Pithonella parva n. sp. from Holes $526 \mathrm{~A}$ and 527 as function of diameter $\left(\mathrm{X}_{1}\right)$ and length $\left(\mathrm{X}_{2}\right)$. Framed square $=$ holotype. 
tern (Plate 3, Figs. 4-6). A circular, irregularly rimmed aperture, $15-20 \mu \mathrm{m}$ in diameter (which is $35-40 \%$ of the cyst diameter), may be present at one pole.

Remarks. Variations in thickness of the inner and outer layer of the cyst wall are interpreted as being the result of diagenetic crystal overgrowth. Primarily the inner layer is only weakly calcified and separated from the outer calcified layer by a (probably) organic wall or membrane. After decomposition of the organic wall a cavity develops (Plate 3, Fig. 8) which is filled by the diagenetically growing inner layer. Similar variations in intensity of primary calcification in Lower Cretaceous Pithonella were observed by Keupp (1981) and interpreted as being the result of environmental effects.

$P$. parva shows similarities in crystal shape of the outer layer to $P$. cylindrica and $P$. krasheninnikovi. The crystals of the latter two species, however, are slightly wider. $P$. parva differs from both mainly by cyst shape and by size and pattern of the distal surface of the inner layer.

Holotype. Length $54 \mu \mathrm{m}$, diameter $47 \mu \mathrm{m}$; thickness of inner wall layer $3.5 \mu \mathrm{m}$, outer layer $1.3 \mu \mathrm{m}$; aperture $19 \mu \mathrm{m}$ but secondarily enlarged; Plate 3, Figures 3, 6, 10; SEM photograph Nos. 89062-89064; film No. 2551/54-58; SEM stub No. 116/10; depository: Geol.-Paläont. Institut, University Kiel.

Type locality and stratum typicum. DSDP Leg 74, Hole 527, Sample 527-25-2, 100-102 cm, Walvis Ridge, Southeast Atlantic Ocean. Late Paleocene (NP9) alternation of nannofossil ooze and chalk.

Age and range of species. $P$. parva is frequent to very rare from the early Paleocene (Danian, P1-b-c, NP1) to the early Pleistocene (N22, NN19).

\section{Pithonella sp. 1}

(Plate 4, Fig. 10)

Description. Cyst strictly spherical, $30-40 \mu \mathrm{m}$ in diameter, showing a small circular aperture $8-12 \mu \mathrm{m}$ in width. The cyst wall is thin $(<5$ $\mu \mathrm{m}$ ) and two-layered. The outer layer is composed of small elongated, rhombohedral crystals arranged slightly oblique to the test surface. Crystals on the surface (0.5-1 $\mu \mathrm{m}$ in width) show smooth faces and tend to fuse, especially in the form of epitaxial overgrowth of large euhedral crystals.

Remarks. This species is extremely small. The surface pattern is unique, but its principal pattern resembles that of $P$. krasheninnikovi and $P$. cylindrica. This species is given in open nomenclature because only a few specimens have been found and the details of the wall structure are not precisely known.

Occurrence. DSDP Leg 74, very rare in Samples 527-32-4, 131-133 $\mathrm{cm}$ and 527-32-4, 69-71 cm; late Maestrichtian.

\section{Pithonella sp. 2}

(Plate 4, Figs. 5-7)

Description. Cyst spherical and about $40 \mu \mathrm{m}$ in diameter. Cyst wall two-layered and about $3 \mu \mathrm{m}$ thick (Plate 4, Fig. 6). Outer layer consists of small, irregular, rhombohedral crystals $(0.2-0.5 \mu \mathrm{m}$ wide, about $1-1.5 \mu \mathrm{m}$ in length) with the long axis arranged perpendicular to the surface. The distal surface therefore reveals a granular pattern, each granule showing smooth rhombohedral crystal faces (Plate 4, Fig. 7). The inner layer is approximately as thick as the outer layer but composed of somewhat coarser crystals (Plate 4, Fig. 6). An aperture has not yet been observed.

Remarks. This species resembles Thoracosphaera deflandrei in surface pattern, but differs clearly in its two-layered cyst wall. It is given in open nomenclature because (1) the wall structure is not clear in all its details, (2) size and shape of an aperture as a major feature have not been observed, and (3) too few specimens have been found to evaluate the range of size and morphology.

Occurrence. DSDP Leg 74, very rare in Samples 526A-29-1, 90-92 $\mathrm{cm}$, early Miocene (NN1, N4), and Sample 526A-38-2, 120-122 cm, late Oligocene (NP23, P18-19).

\section{Pithonella sp. 3}

(Plate 4, Figs. 1-4)

Description. Cyst spherical and about $45 \mu \mathrm{m}$ in diameter. Cyst wall is three-layered (about $8 \mu \mathrm{m}$ thick) and shows small granular crystals (up to $1 \mu \mathrm{m}$ in diameter) composing the proximal layer (Plate 4, Figs. $3-4)$. The outer layer is formed by irregular-sized plate-like crystals which are arranged obliquely to the distal surface (Plate 4, Fig. 2). The middle layer is composed of irregular-shaped crystals, about $3 \mu \mathrm{m}$ in length and about $1 \mu \mathrm{m}$ in width, arranged perpendicular to the proximal and outer layer.

Remarks. The middle layer, grown from the proximal and outer layer respectively into a primarily open space between both layers, seems to be of diagenetic origin. Only one specimen was observed.

Occurrence. DSDP Leg 74, one specimen in Sample 526A-31-1, 96-98 cm, late Oligocene (NP25, N4).

\section{ACKNOWLEDGMENTS}

The author would like to thank W. Coulbourn, U. Pflaumann, C. Samtleben, and G. Wefer for valuable suggestions and critical reading of the manuscript. Technical help by I. Bornhöft, W. Reimann, U. Schuldt, and M. Westphal is gratefully acknowledged. Financial support was given by the Deutsche Forschungsgemeinschaft.

\section{REFERENCES}

Bein, A., and Reiss, Z., 1976. Cretaceous Pithonella from Israel. Micropaleontology, 22:83-91.

Bignot, G., and Lezaud, L., 1964. Contribution à l'étude des Pithonelles de la craie parisienne. Rev. Micropaleont., 7/2:138-152.

Bolli, H. M., 1974. Jurassic and Cretaceous Calcisphaerulidae from DSDP Leg 27, eastern Indian Ocean. In Veevers, J. J., Heirtzler, J. R., et al., Init. Repts. DSDP, 27: Washington (U.S. Govt. Printing Office), 843-907.

1978a. Cretaceous and Paleogene Calcisphaerulidae from DSDP Leg 40, southeastern Atlantic. In Bolli, H. M., Ryan, W. B. F., et al., Init. Repts. DSDP, 40: Washington (U.S. Govt. Printing Office), 819-837.

1978b. Upper Jurassic Calcisphaerulidae from DSDP Leg 44, Hole 391C, Blake-Bahama Basin, western North Atlantic. In Benson, W. E., Sheridan, R. E., et al., Init. Repts. DSDP, 44: Washington (U.S. Govt. Printing Office), 911-919.

1980. Calcisphaerulidae and Calpionellidae from the Upper Jurassic and Lower Cretaceous of Deep Sea Drilling Project Hole 416A, Moroccan Basin. In Lancelot, Y., Winterer, E. L., et al., Init. Repts. DSDP, 50: Washington (U.S. Govt. Printing Office), 525-543.

Keupp, H., 1979. Lower Cretaceous Calcisphaerulidae and their relationship to calcareous dinoflagellate cysts. Bull. Centre Rech. Explor.-Prod. Elf-Aquitaine, 3/2:651-663.

1980. Pithonella patriciacreeleyae Bolli 1974, eine kalkige Dinoflagellaten-Zyste mit innerer Paratabulation (Unter-Kreide, Speeton/SE-England). Neues Jahrb. Geol. Palaontol. Monatsh., 1980, Pt. 9:513-524.

1981. Die kalkigen Dinoflagellaten-Zysten der borealen Unter-Kreide (Unter-Hauterivium bis Unter-Albium). Facies, 5:1-90.

Masters, B. A., and Scott, R. W., 1978. Microstructure, affinities and systematics of Cretaceous calcispheres. Micropaleontology, 24: 210-221.

Pflaumann, U., and Krasheninnikov, V. A., 1979. Cretaceous calcisphaerulids from DSDP Leg 41, eastern North Atlantic. In Lancelot, Y., Seibold, E., et al., Init. Repts. DSDP, Suppl. to Vols. 38, 39, 40, and 41: Washington (U.S. Govt. Printing Office), 817-839.

Rögl, F., 1976. Danian Calcisphaerulidae of DSDP Leg 35, Site 323, southeast Pacific Ocean. In Hollister, C. D., Craddock, C., et al., Init. Repts. DSDP, 35: Washington (U.S. Govt. Printing Office), 701-711.

Villain, J. -M., 1977. Les Calcisphaerulidae: Architectures, calcification de la paroi et phylogenese. Palaeontographica Pt. A, 159: 139-177.

Vogler, J., 1941. Ober-Jura und Kreide von Misol (NiederländischOstindien). Palaeontographica, Suppl. 4, Pt. 4:243-293.

Wanner, J., 1940. Gesteinsbildende Foraminiferen aus Malm und Unterkreide des ostlichen Ostindischen Archipels nebst Bemerkungen über Orbulinaria Rhumbler und andere verwandte Foraminiferen. Pal. Z., 22:75-99. 

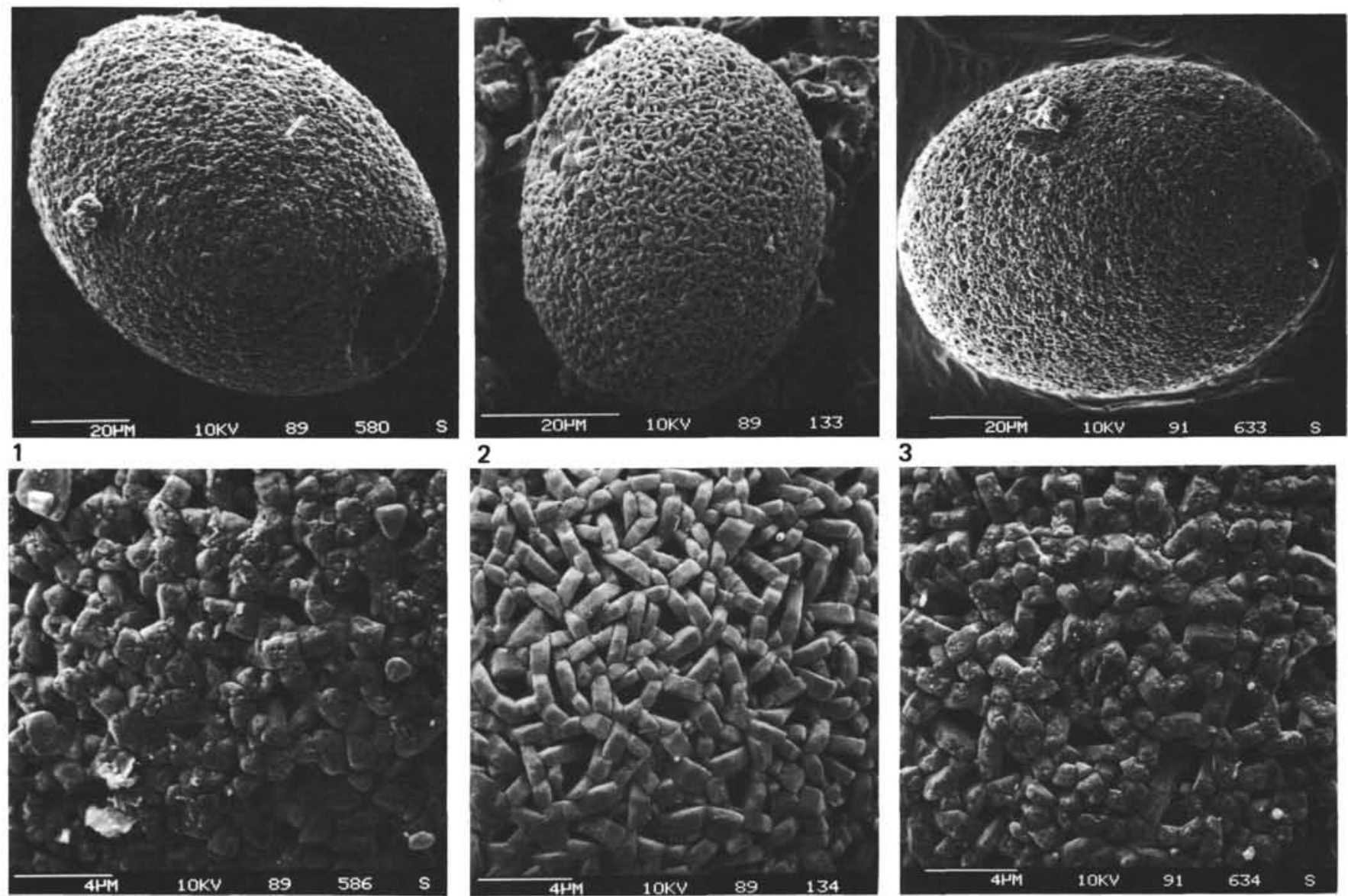

4
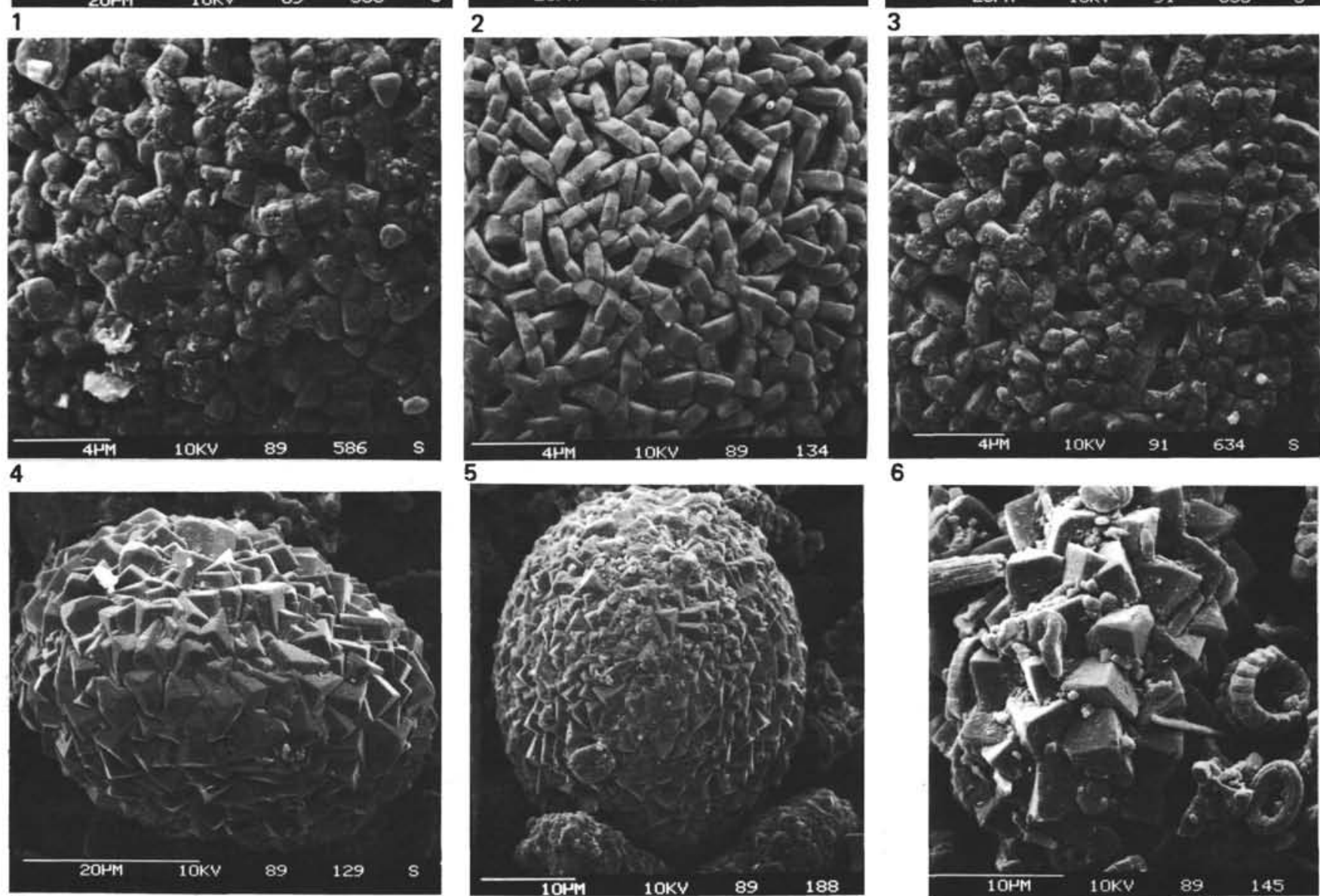

6

8

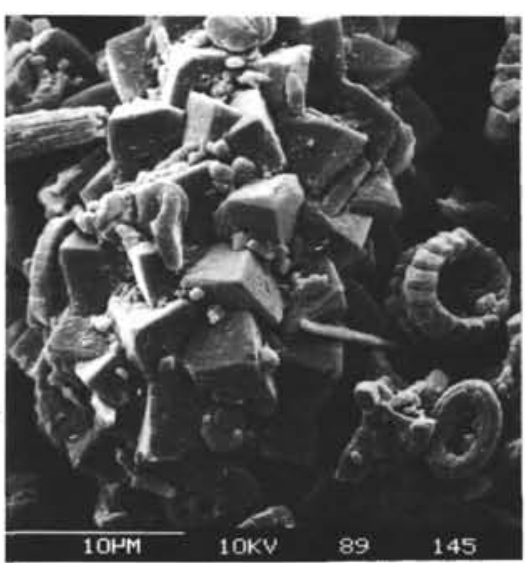

9

Plate 1. Middle Maestrichtian to early Danian Pithonella krasheninnikovi Bolli. 1,4. P. krasheninnikovi, Sample 527-32-4, 37-39 cm; early Danian (G. eugubina Zone). 2,5. P. krasheninnikovi, Sample 527-33-1, 60-61 cm; late Maestrichtian (Micula mura). 3,6. P. krasheninnikovi, Sample 527-34-4, 8-10 cm; late Maestrichtian $(M$. mura/L. quadratus). Note variability in crystal habitus of distal surface of outer layer in Figures 4-6. 7. P. krasheninnikovi, outer layer completely removed; Sample 527-33-1, 60-61 cm; late Maestrichtian $(M$. mura). 8. $P$. krasheninnikovi, outer layer completely removed, Sample 527-38-4, 51-53 cm; middle Maestrichtian. 9. P. cf. krasheninnikovi showing extremely large crystals of the inner layer, Sample 527-33-1, 60-61 cm; late Maestrichtian (M. mura). 

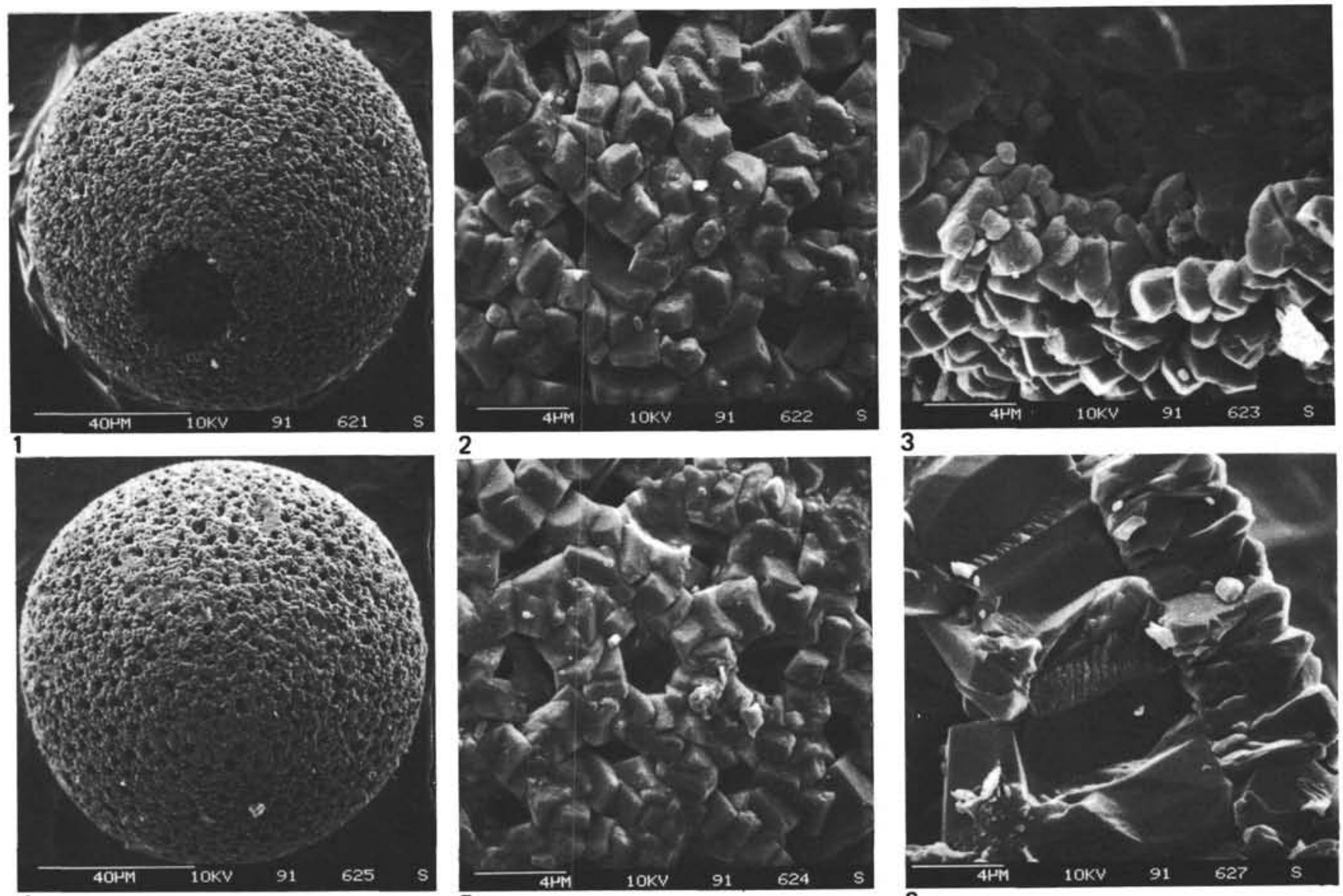

4

5
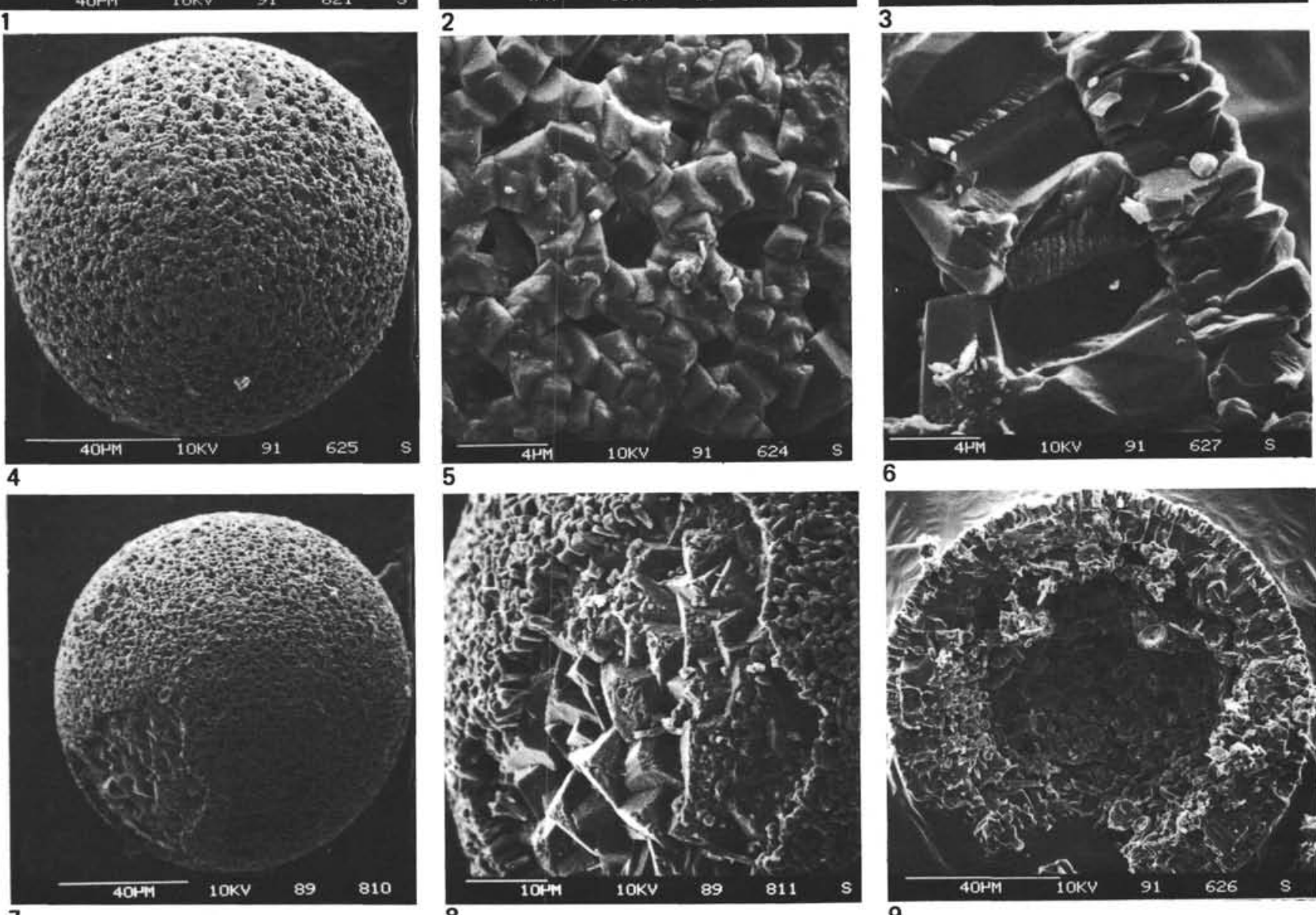

6

8

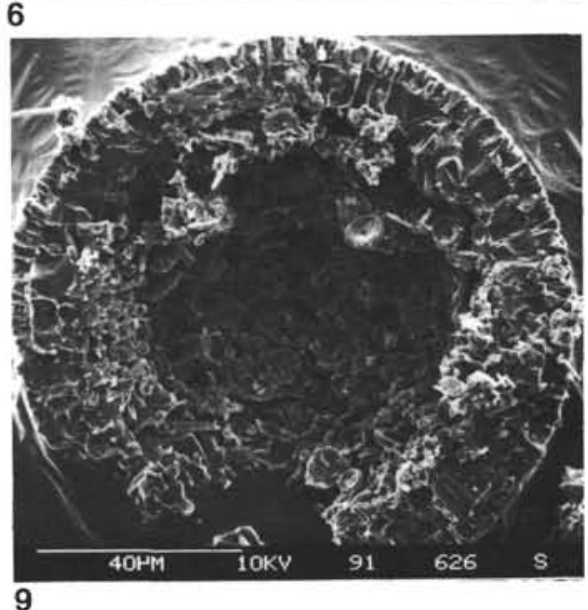

Plate 2. Middle Maestrichtian to early Danian Pithonella globosa n. sp., Sample 527-34-4, 8-10 cm. 1-3. Holotype showing the small circular archaeopyle (1), ultrastructural details of outer layer distal surface (2), and two-layered test wall (3). 4-5. Paratype showing details of outer layer distal surface. 6,9. Paratype artificially broken revealing details of two-layered test wall. 7-8. Paratype with partially removed outer layer showing densely packed large crystals of inner layer distal surface. 

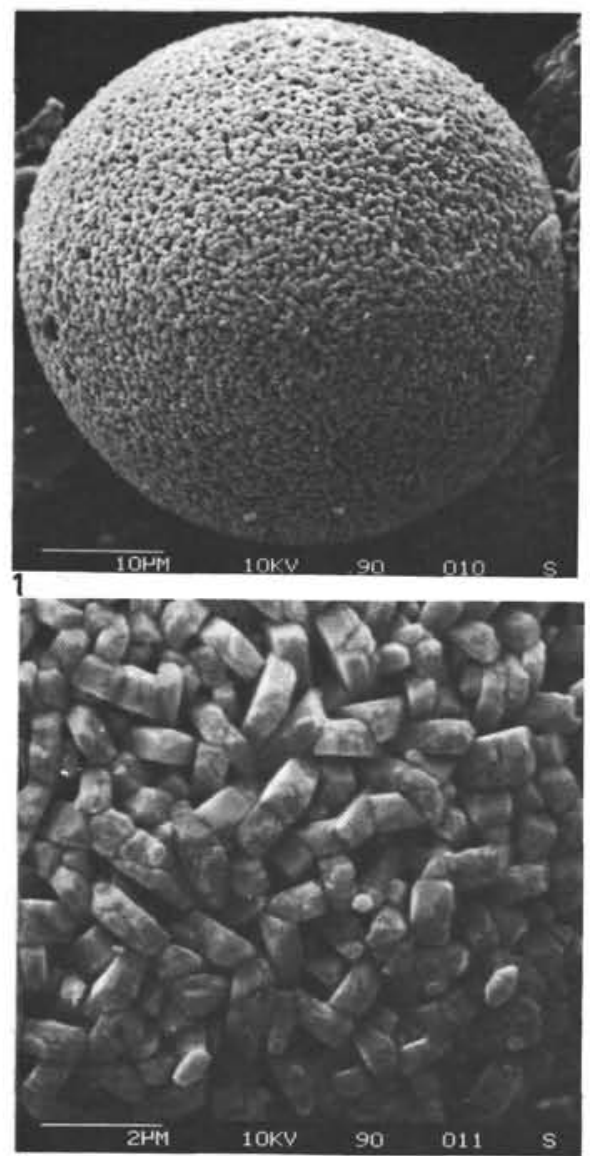

4

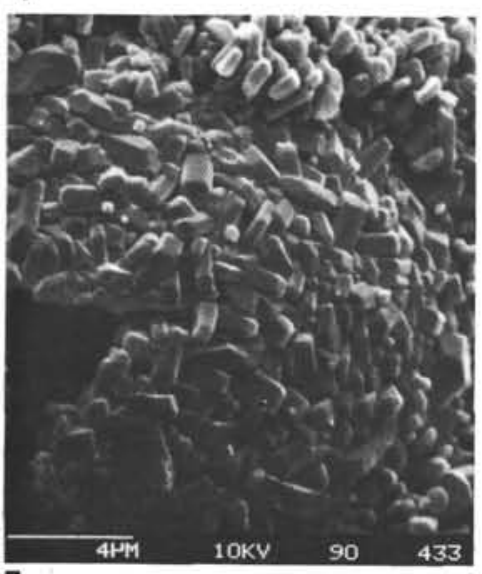

7

8

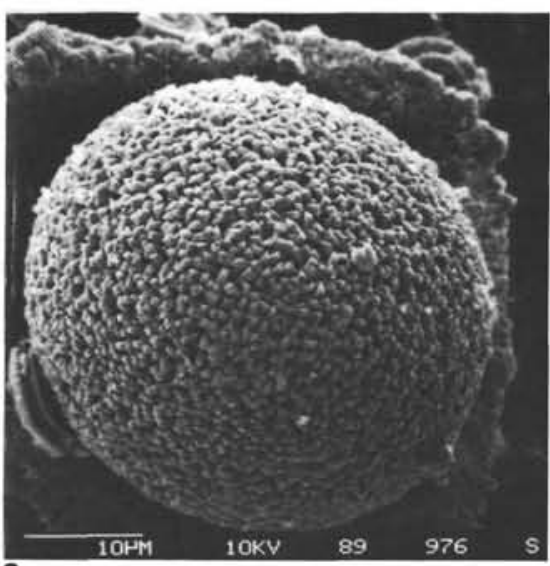

2

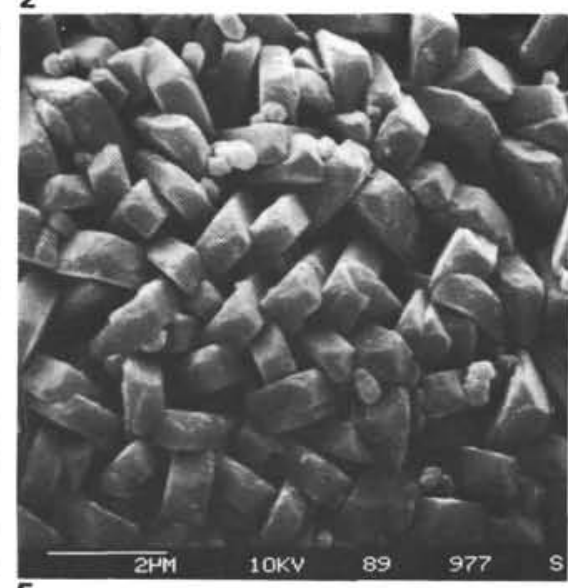

5

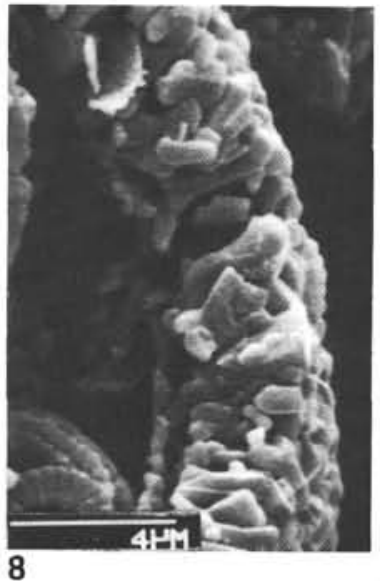

9

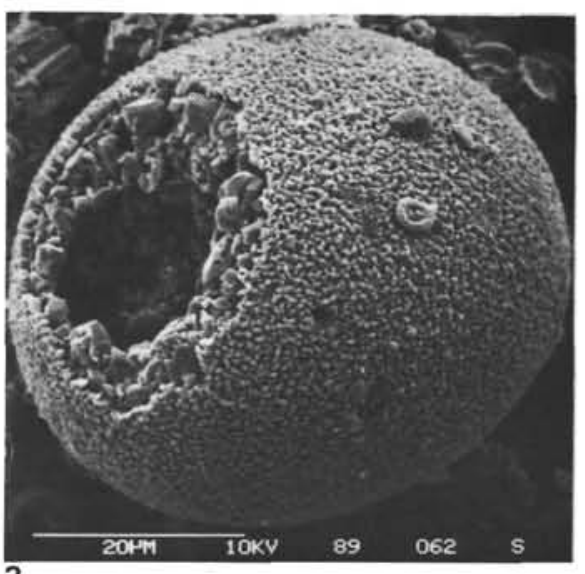
3

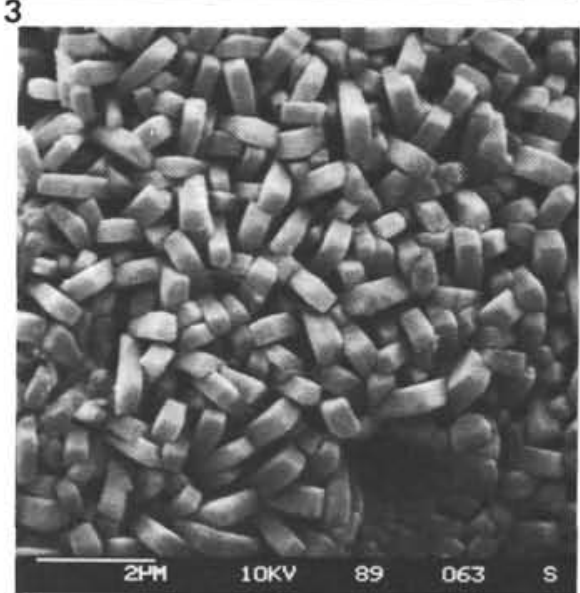

6

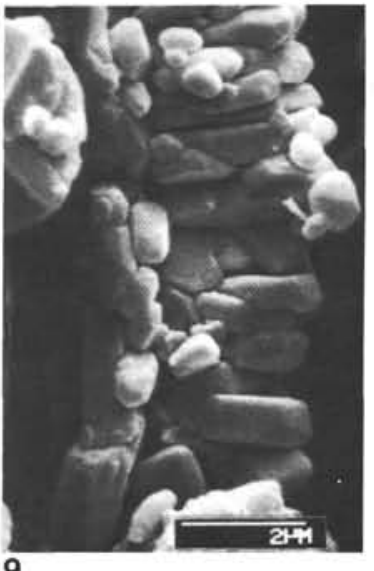

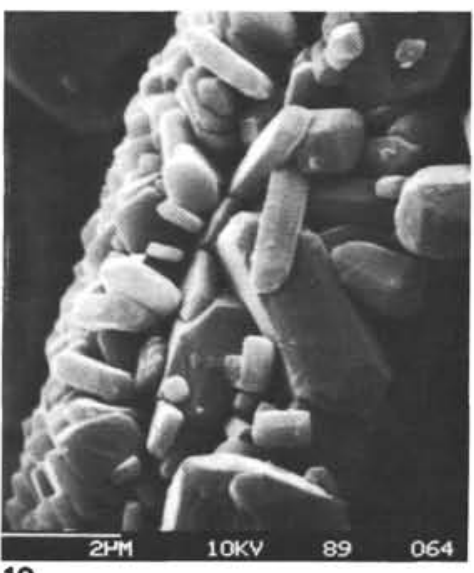

10

Plate 3. Late Paleocene to late Miocene Pithonella parva n. sp.. 1,4. Paratype of subspherical shape showing outer layer crystals composed of granular subunits, Sample 526A-12-1, 55-57 cm; late Miocene (NN10). 2,5. Paratype, very small cyst showing relatively large crystals, Sample 526A-10-1, 139-141 cm; late Miocene (NN10). 3,6,10. Holotype showing ovoid cyst type with small crystals on distal surface (6) and twolayered test wall showing progressive diagenesis, Sample 527-25-2, 100-102 cm; late Paleocene (NP9). 7. Paratype, distal surface of inner layer, Sample 526A-29-1, 90-92 cm; early Miocene (NN1). 8. Paratype, two-layered cyst wall showing early stage of diagenesis with thin inner and thick outer layer, Sample 526A-16-1, 64-66 cm; middle Miocene (NN7). 9. Paratype, two-layered cyst wall showing progressive stage of diagenesis by thickening of inner wall, Sample 526A-23-1, 105-107 cm; early Miocene (NN1). 

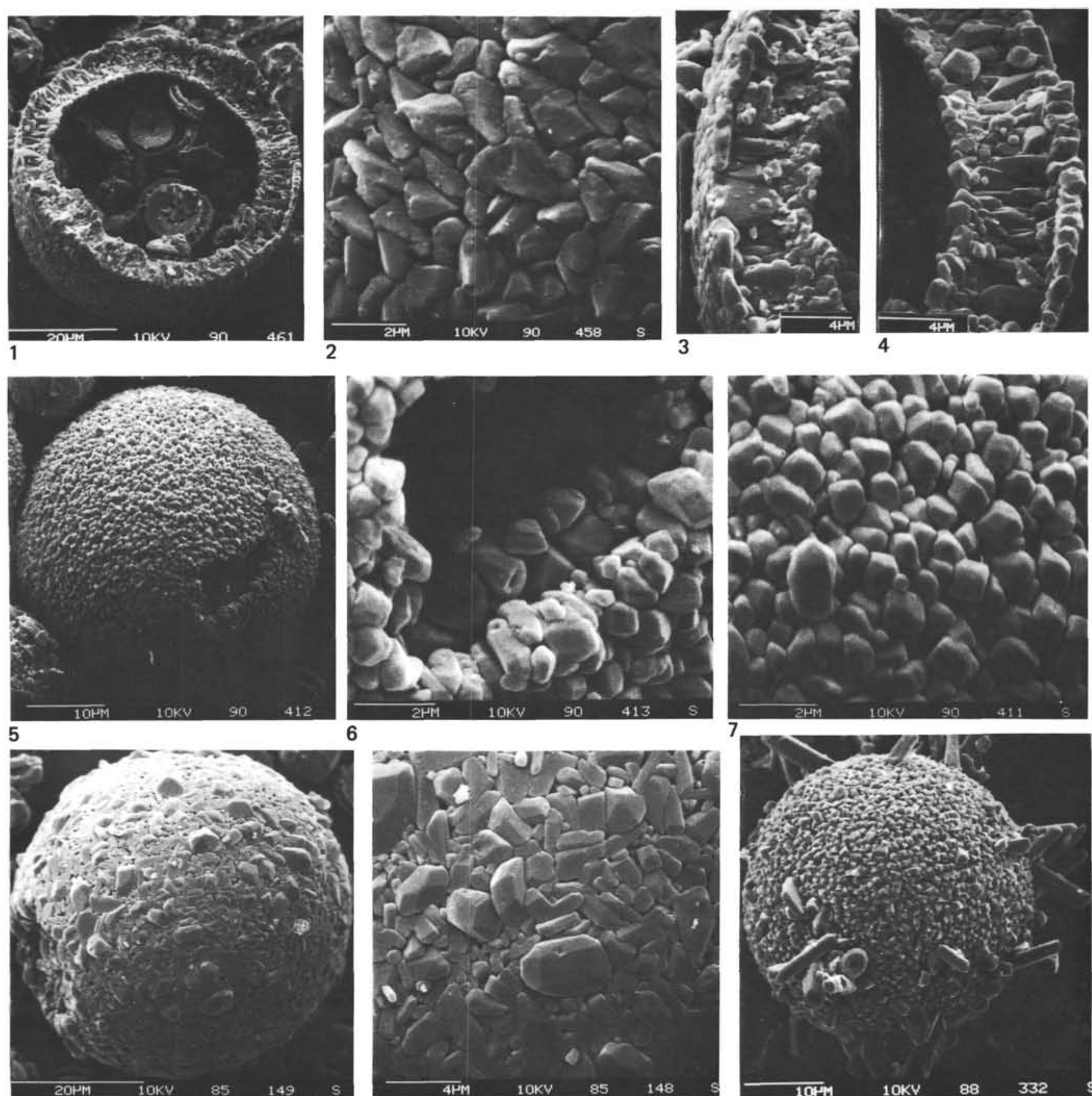

6
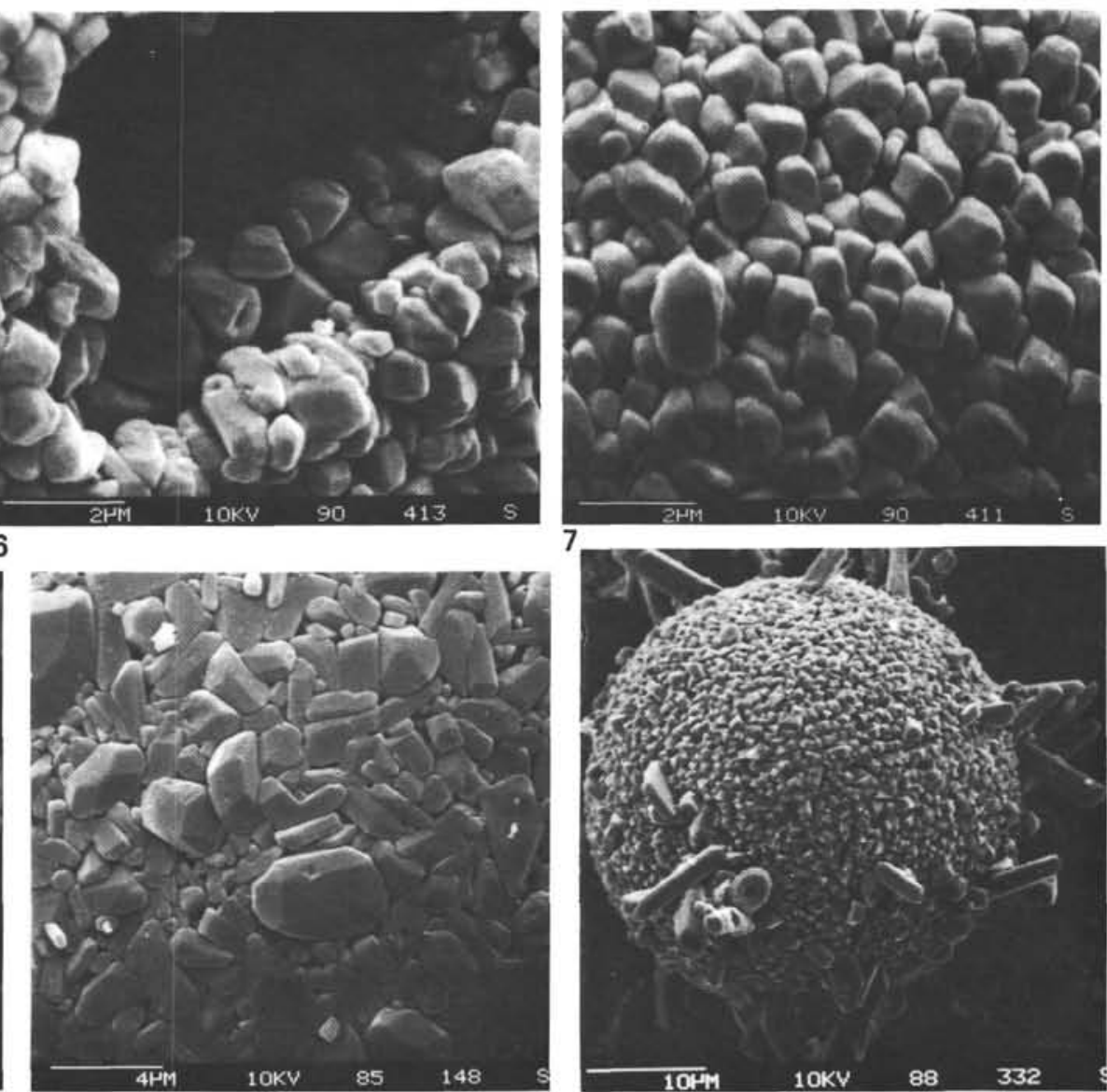

9

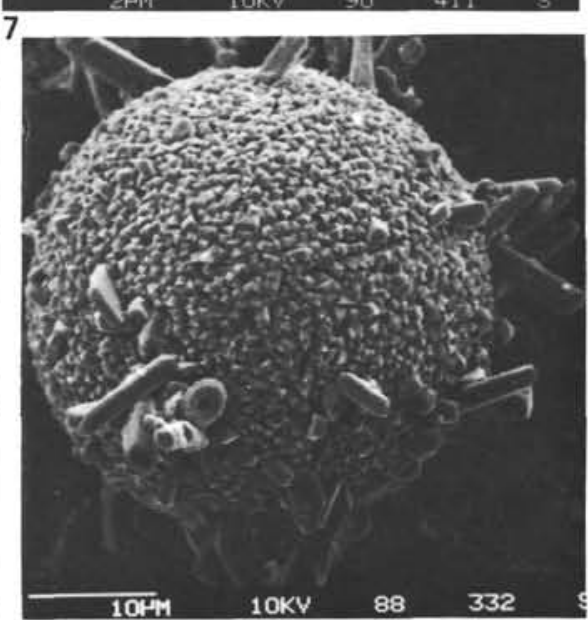

10

Plate 4. 1-4. Pithonella sp. 3, spherical cyst type showing three-layered wall, Sample 526A-31-1, 96-98 cm; late Oligocene (NP25). 5-7. Pithonella sp. 2, spherical cyst type showing two-layered wall, Sample 526A-29-1, 90-92 cm; early Miocene (NN1). 8-9. Pithonella parva n. sp. showing distal surface of inner layer, outer layer completely removed, Sample 527-23-1, 35-37 cm; late Paleocene (NP9). 10. Pithonella sp. 1, spherical cyst type showing extremely small crystals and characteristic diagenetic crystal overgrowth, Sample 527-32-4, 69-71 cm; late Maestrichtian (Micula mura). 